剣道の強化練習が血清過酸化脂質に抽よぼす影響 井奈波良一* 栗山 典子* 平尾真規子** 常川 茂**

\title{
Effect of Training Camp of Kendo on Serum Lipoperoxide
}

\author{
Ryoichi INABA*, Noriko KURIYAMA*, Makiko HIRAO** \\ and Shigeru TSUNEKAWA**
}

To investigate whether exercise is beneficial for prevention against aging or not, serum lipoperoxide, considered to promote aging, was measured in male students before and after taking part in a traning camp of Kendo (including $4 \mathrm{~km}$ running a day).

The results obtained were as follows.

1) The distance which the students could run in 12 minutes after the training camp was significantly longer than that before the training camp.

2) Serum lipoperoxide levels in the students soon after the trainng camp were significantly lower than those before the training camp. However, there were no significant differences in serum lipoperoxide levels between before and 1 month after the training camp.

3) Serum total cholesterol, $\beta$-lipoprotein, HDL-cholesterol, trigliceride and uric acid levels in the students did not change significantly following the taining camp of Kendo.

From these results, it can be considered that the training camp of Kendo in this study was beneficial not only for promotion of stamina but also for prevention against aging.

\section{I 緒言}

近年, 運動が老化防止などに役立つとして, 中 高年層では, ジョギングなどの運動がさかんに行 なわれている，この老化防止に対する運動の効果 を判断するためにはどんな指標を用いて評価する のが良いかが問題となる。 その一つの方法として 老化に関する生化学的検査の測定値を指標として 用いることによってそれが可能になると考えられ る。

近年, 生体内の過酸化脂質の増加が, 動脈硬化 などの老化現象に関連しているとする報告がいく
つかなされてきた(秦1978，平井1980)。したがっ

て, 過酸化脂質は老化防止の指標のひとつとして 有用であると推定される。これまで運動の老化防 止効果を生体内過酸化脂質の変動で把握した報告 は少ない，そこで，今回，著者らは，運動として 剣道をとりあげ，大学医学部剣道部員を対象に， 試合のための強化練習による血清過酸化脂質の変 動を検討したので報告する。

\section{II 対象と方法}

1. 対象

18 23歳 (平均 22.5 歳) の金沢大学医学部男子

* 金沢大学医学部公衆衛生学教室

** 新潟大学医学部衛生学教室

* Department of Public Health, School of Medicine, Kanazawa University.

** Department of Hygiene and Preventive Medicine, Niigata University School of Medicine. 
剣道部員11名を対象にした. 対象者の強化練習実 施前の身長拉よび体重を平均値土標準偏差で示す と，それぞれ $172.9 \pm 1.7 \mathrm{~cm}, 65.5 \pm 1.9 \mathrm{~kg}$ であっ た.

\section{2. 方法}

剣道の試合のための強化練習は，昭和59年 5 月 28 日（月）午後 5 時 30 分から 5 月 31 日（木）午後 7 時までの 4 日間にわたって実施された。練習内 容は，午前 7 時 00 分から 7 時 30 分までの練習は, 竹刀の素振り練習とランニング約 $4 \mathrm{~km}$ であり, 午 後 5 時 30 分から 7 時 30 分までの練習は, 竹刀の素 振り，試合げいこを中心としたものであった．練 習時間以外の生活および食事の制限は行なわな かった.

気温は, 午前の練習時では $14 \pm 2{ }^{\circ} \mathrm{C}$, 午後の練

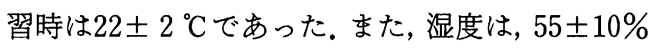
であった。

本研究に先立つ約 1 力月前から対象者は, 全員 週 2 回(月および木), 午後 5 時 30 分より約 1 時間 半の練習を行なってきていた。また，対象者は， 全員強化練習終了後, 試合を 6 月 3 日（日）に行 なったのみで，この日を除いた 1 力月間は練習を しなかった。

5 月 28 日（月），6月 1 日（金）および 6 月 30 日 (土)の午前 7 時 30 分に空腹状態で採血を肘静脈よ り行なった。また，強化練習の効果を把握する目 的で， 5 月 28 日㧍よび 6 月 1 日の採血後， 12 分間 走を実施し，検討した。

測定項目は, 血清中の Creatine phosphokinase (CPK), Lactic dehydrogenase (LDH), 総コレ ステロール(TCH), $\beta$-lipoprotein(BLP), HDL コレステロール (HDLC), 中性脂肪 (TG), 過酸 化脂質（LPO）および尿酸である，血清 CPK, LDH，TCH，BLP，HDLC，TG 抢よび尿酸は， 自動分析装置(日立)を用いて定量した。血清 LPO は, 八木 (1976) の方法にて分光蛍光光度計 (Farrand MK-1）を用いて定量した.

結果は, 平均値士標準誤差で示した。有意差検 定は, Student $の \mathrm{t}$ 検定または, 一元配置分散分析 後, 多重比較をSheffé の方法により行なった。

\section{III 成 績}

1. 強化練習の 12 分間走に掠よぼす効果 強化練習によって12分間走距離は11名全員が延 長し, 平均值は $2055.0 \pm 17.5 \mathrm{~m}$ から $2285.0 \pm 24.5$ $\mathrm{m}$ と有意に延長した $(\mathrm{p}<0.01)$.この結果は，こ の強化練習に持久力促進効果があったことを示し ている.

2. 強化練習による血清 $\mathrm{CPK}, \mathrm{LDH}$ の变化

Table 1 に強化練習による筋原性酵素である血 清 $\mathrm{CPK}, \mathrm{LDH}$ の変化を示した。血清 $\mathrm{CPK}$ は, 強 化練習終了直後には，11名全員が練習前より上㫒

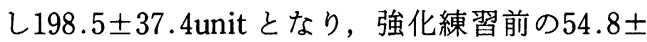
7.3unit の約 3.6 倍まで上昇した $(\mathrm{p}<0.01)$. しか 乙, 強化練習終了 1 力月後には, $32.4 \pm 4.0 u n i t$ と 練習前より有意に低下した $(\mathrm{p}<0.05)$ 。一方，血 清 LDH は, 練習終了直後には, 11名全員練習前よ

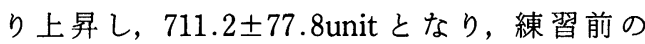
430.2 \pm 19.0 unit の約1.7倍になった $(\mathrm{p}<0.05)$. 終了 1 カ月後には, $371.5 \pm 14$.1unit となり, 練習 前と有意差がなくなった。

3. 強化練習による血清 TCH, BLP, HDLC 括 よび TG の変化

Table 2 に強化練習による血清 $\mathrm{TCH}, \mathrm{BLP}$ お よびTGの変化を示した，血清 TCH，BLP， HDLC およびTGには，強化練習をしても特記す べき変化は見られなかった。

4. 強化練習による血清 LPO 打よび尿酸の変 化

Fig. 1 に強化練習による血清 LPO の変化を示

Table 1 Changes in the levels of serum CPK and LDH in male students following the training camp of Kendo.

\begin{tabular}{lcc}
\hline & CPK(unit) & LDH(unit) \\
\hline Before & $54.8 \pm 7.3$ & $430.2 \pm 19.0$ \\
\hline Soon after & $198.5 \pm 37.4^{* *}$ & $711.2 \pm 7.8^{*}$ \\
\hline 1 month after & $32.5 \pm 4.0^{*}$ & $371.5 \pm 4.1$ \\
\hline
\end{tabular}

Each value represents mean $\pm \mathrm{SE}$.

${ }^{* *} \mathrm{p}<0.01,{ }^{*} \mathrm{p}<0.05$, compared with the levels before the training camp. 
Table 2 Changes in the levels of serum lipid in male students following the training camp of Kendo.

\begin{tabular}{lcccc}
\hline & $\begin{array}{c}\text { Total cholesterol } \\
(\mathrm{mg} / \mathrm{dl})\end{array}$ & $\begin{array}{c}\text { HDL cholesterol } \\
(\mathrm{mg} / \mathrm{dl})\end{array}$ & $\begin{array}{c}\beta \text {-lipoprotein } \\
(\mathrm{mg} / \mathrm{dl})\end{array}$ & $\begin{array}{c}\text { Trigliceride } \\
(\mathrm{mg} / \mathrm{dl})\end{array}$ \\
\hline Before & $159.5 \pm 8.5$ & $43.8 \pm 1.4$ & $466.1 \pm 28.2$ & $76.5 \pm 7.6$ \\
\hline Soon after & $157.7 \pm 8.9$ & $45.4 \pm 2.0$ & $405.2 \pm 24.0$ & $63.2 \pm 4.2$ \\
\hline 1 month after & $166.4 \pm 7.6$ & $44.4 \pm 2.0$ & $495.2 \pm 30.0$ & $80.5 \pm 10.1$ \\
\hline & & & Each value represents mean $\pm \mathrm{SE}$.
\end{tabular}

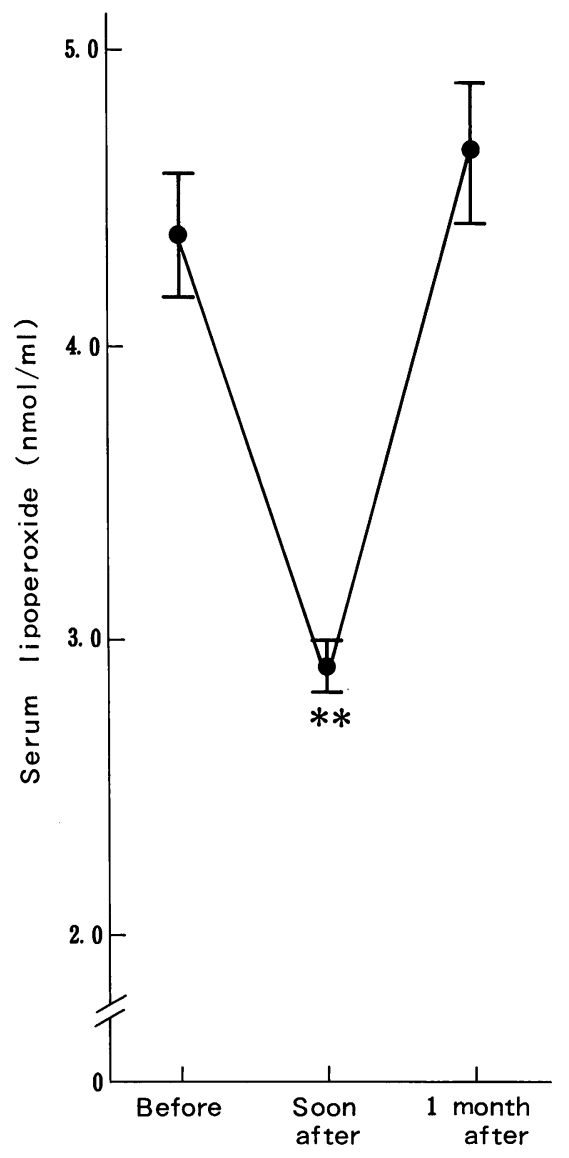

Fig. 1 Changes in the levels of serum lipoperoxide in male students following the training camp of Kendo. Each value represents mean \pm SE. ${ }^{* *} \mathrm{p}<0.01$, compared with the levels before the training camp.

した. 血清 LPO は, 強化練習前には, $4.37 \pm 0.21$ $\mathrm{nmol} / \mathrm{ml}$ であったが, 練習終了直後には, 11名全

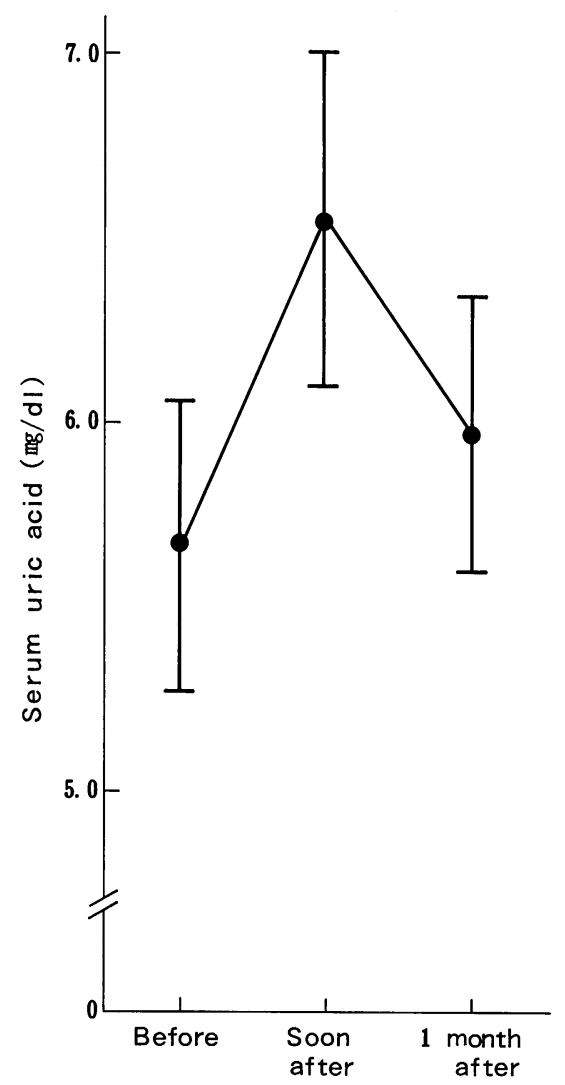

Fig. 2 Changes in the levels of serum uric acid in male students following the training camp of Kendo. Each value represents mean $\pm \mathrm{SE}$.

員が練習前より低下し, $2.91 \pm 0.09 \mathrm{nmol} / \mathrm{ml}$ と練 習前より有意に低下した $(\mathrm{p}<0.01)$ ，乙かし，練 習終了 1 力月後には, $4.65 \pm 0.24 \mathrm{nmol} / \mathrm{ml}$ と練習 前の値と差がなくなった. Fig. 2 に強化による血 清尿酸の変化を示した。血清尿酸には, 強化練習 
をしても特記すべき変化は見られなかった。

\section{IV 考察}

本研究で, 著者らは，5月末に行なわれた剣道 の強化練習によって, 男子剣道部員 (大学生) の 血清 LPO が練習前より有意に低下することを観 察した。しかし，練習終了 1 力月後には練習前と 差がなくなった。この際, 同時に血清 CPK および $\mathrm{LDH}$ の有意な上昇を観察したが，血清 $\mathrm{TCH}$, BLP，TG 拈よび尿酸では有意な变化は認められ なかった。

本研究では強化練習に参加しなかった者の成績 については検討していないので断定はできない が, 今回, 行なった剣道の強化練習は, 対象者全 員に練習終了後の12分間走距離が練習前より延長 していたことから持久力の促進効果があったと推 測される.

動脈硬化や老化現象を促進するとされる過酸化 脂質（秦1978，平井1980）の変動と運動との関係 について, 提ら（1983）は, 若年者（19２1歳） では運動筋での低酸素状態が扣こると考えられる 過激な運動によって血浆 LPO が上昇することを 報告している。一方，マウスやラットでは，生体 にとってストレスの少ない運動を持続的に行なわ せると血中の LPO が低下することも報告されて いる(荒尾ら1986，1987，木下ら1985). 本研究で, 著者らは, 剣道の強化練習によって男子部員の血 清 LPO が有意に低下寸ることを観察したが，堤 ら（1983）の過激な運動の場合と異なり，ストレ スの少ない運動で観察された動物実験の場合と同 じょうに低下していた。したがって, 本研究で行 なわれた剣道の強化練習はそれほど過激な運動で はなく，むしろ生体にとって好影響をもたらす運 動であったとも考えられる。しかし，強化練習終 了後 1 力月後の血清 $\mathrm{LPO}$ は練習前の值と差がな くなった，このことは，運動の効果を維持するた めには，運動を持続する必要があることを示唆す るものと考えられる。

生体には過酸化脂質の形成を妨害する防禦機構 としてスーパーオキサイドディスムターゼ
(SOD)やグルタチオンパーオキシターゼ(GSSH) 等の酸化還元酵素が存在し, 赤血球, 肝, 肺, 腎 などに広く分布し，その働きによって組織細胞で の過酸化脂質の形成を最小限に保っているとされ ている（堤ら1983）。荒尾ら（1986，1987）は，長 期間適度な自発運動を継続したラットでは, 非運 動群に比べて肝，骨格筋に括けるSOD 活性が有 意に高く維持されていたことを報告している。こ のことから，今回の剣道の強化練習によって血清 LPO が練習前より有意に低下した原因のひとつ として，実際には測定しなかったが，肝や骨格筋 に颃けるSOD 活性等が高まったためではないか と想定できよう. 今後, この方面の研究を進めて いく必要がある。

さて，尿酸が生成される過程では，キサンチン オキシターゼの活性化にともない同時に産生され る一重項酸素の酸化作用により過酸化脂質も産生 されることが知られている(吉田と浅野1988). 角 田ら（1987）は, 血中の尿酸の上昇の見られた運 動では，血中の LPO の上昇も観察されたことを 報告している。本研究では, 男子部員の血清尿酸 には，強化練習をしても有意な变化は見られな かった。このことが, 本研究に打ける剣道の強化 練習後に血清 LPO の上昇が見られなかった原因 のひとつと推定できる.

血清 CPK は，運動負荷量あるいは筋肉に対す る負担度をよく反映する酵素と考えられている （井川1984）。井川（1984）は，1週間のテニスの 合宿訓練の場合, 血清 CPK は, 合宿前に27.0unit であったのが終了時には405.0unit と前值よりの 増加を示し, 終了 2 日後でも2.5.6unit で前值に 回復しなかったことを報告している．今回行なっ た剣道の強化練習で血清 CPK は終了直後には 198.5unit と, 前值の約 4 倍まで増加していた。こ の結果より, 今回の強化練習は, 井川 (1984) の 報告したテニスの合宿訓練ほど運動負荷量は多く なく，この意味でも運動としては適度であったと 考えられる.

運動負荷が長時間におよぶ時には血清 LDH も 上昇するとされている(井川1984)，今回の剣道の 
強化練習では, 終了直後の血清 LDH は前値より 約65\%上昇していた。井川（1984）は，血清 CPK の結果から今回の強化練習より運動負荷量が大き いと考えられる前述のテニス合宿では，血清

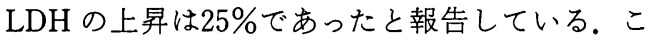
れらのことより, 血清 $\mathrm{LDH}$ の上昇の程度は, 運動 負荷量のみならず運動の種類によっても異なるこ とが想定できる。

本研究では, 剣道の強化練習の血清脂質に拉よ ぼす影響についても検討した。運動と血中 TCH との関係については，これまで数多くの研究がな されているが，一定の見解が得られていない（寺 尾1984). 今回行なった剣道の強化練習では, 血清 $\mathrm{TCH}$ には何らの変化も観察されなかった。運動 と血中 HDLC に関しては，血中 HDLC は一過性 の全身運動では変化が見られないとされている。 今回行なった剣道の強化練習でも, 血清 HDLCの 変化は観察できなかった. Carlson と Mossfedt （1964）は，長時間にわたるスキーの距離レース後 の血清 TGは，レース前より有意に低下したこと を報告している。 また，木村（1987）は，軽中等 度の運動を長期間にわたって継続している者は， そらでない者より血清 TG，BLPが有意に低かっ たことを報告している。しかし，今回行なった強 化練習では, 血清 TG，BLP には有意な変化は観 察されず，血清 TG，BLP が低下するためには強 化練習をさらに継続することが必要であったので はないかと考えられる。

\section{V 結 論}

運動が老化防止に役立つかどうかを検討する目 的で，老化を促進するとされる血清 LPOを男子 大学生を対象として, 剣道の強化練習 (1 日に $4 \mathrm{~km}$ のランニングを含む）前後に測定し，以下の結果 を得た。

1. 12 分間走距離は, 強化練習により練習前より 有意に延長した。

2. 血清 LPO は, 強化練習終了直後には, 練習 前より有意に低下したが，終了1 月月後には，練 習前と差がなかった。
3. 血清 TCH，BLP，HDLC，TG および尿酸 については, 強化練習による有意な変化は観察で きなかった。

以上の結果より, 本研究に打ける剣道の強化練 習は，一時的ではあるが，持久力の促進よみなら ず，老化の防止にも役立った可能性があると考兄 られた。

謝辞：本研究に御協力いただいた金沢大学医学部剣 道部諸氏に感謝の意を表する。

\section{文献}

荒尾 孝, 生山 匡, 峯岸由紀子(1986)： ラットの長 期自発運動が血清拉よび組織中の過酸化脂質含量と その関連酵素活性に及ぼす影響，体力科学， 35,323

荒尾 孝, 生山 匡, 峯岸由紀子 (1987)：若齡ラッ トに㧍ける自発運動トレーニングが血清拉よび組織 中の過酸化脂質含量と Superoxide Dismutase 活性 に及ぼす影響，体力科学， 36,567

Carlson, L.A. \& Mossfeldt, F. (1964): Acute effects of prolonged, heavy exercise on the concentration of plasma lipid and lipoprotein in man, Acta Physiol. Scand., 62, 51-59

秦 臀哉 (1978)：動脈硬化と過酸化脂質, 代謝, 15, 1336-1338

平井俊策 (1980)：老化と過酸化脂質，臨床栄養，57, $727-732$

井川幸雄 (1984)：運動々酵素，臨床栄養，65, 518-521 角田 聡, 田中喜代次, 渡辺一志, 喜多尾浩代, 中塘 二三生（1987）：Vitamin $\mathrm{E}$ 投与後の運動による脂 質過酸化について，体力科学，36, 351

木村みさか（1987）：血清脂質に良い影響を及ぼす運 動習慣の検討 (アポ蛋白の比較検討を加え), 体力科 学, 36,394

木下修三, 垣平博臣, 由井宏道 (1985) : 老齢マウス の過酸化脂質に及ぼす運動負荷の影響について，日 本公衛誌，32，301-304

寺尾 保(1984)：運動と脂質代謝, 臨床栄盖, 65, 503 $-507$

堤 達也, 青木和江, 後藤芳雄, 喜多尚武(1983)：運 動筋での低酸素状態が考えられる断続運動時の血浆 過酸化脂質及び中性脂質の動態，体力研究，54，22 $-37$

八木国夫（1976）：血浆過酸化脂質の微量定量, 日本 医事新報, 2748, 100-101

吉田伸一, 浅野孝雄 (1988): 虚血脳病態における リーラジカルの役割, 日本臨床, 46, 2179-2189

（受稿 1989.4.4 ) 